\title{
Nutrient Properties of Tithonia-enriched Liquid Organic Fertilizer as Affected by Different Types of Animal Feces and Its Effects on Fresh Weight of Loose-leaf Lettuce (Lactuva sativa L.)
}

\author{
Fahrurrozi Fahrurrozi $^{\mathrm{a} 1}$, Zainal Muktamar ${ }^{\mathrm{b}}$, Nanik Setyowati ${ }^{\mathrm{a}}$, Mohammad Chozin $^{\mathrm{a} 2}$, Sigit Sudjatmiko ${ }^{\mathrm{a} 3}$ \\ ${ }^{a}$ Department of Crop Production, University of Bengkulu, Bengkulu 38121, Indonesia \\ E-mail: ${ }^{1}$ fahrurrozi@unib.ac.id, ${ }^{2}$ mchozin@unib.ac.id, ${ }^{3}$ sigitsudjatmiko@unib.ac.id \\ ${ }^{b}$ Department Soil Science, University of Bengkulu, Bengkulu 38121, Indonesia \\ E-mail:muktamar@unib.ac.id
}

\begin{abstract}
Liquid organic fertilizer (LOF) has been increasingly practiced in organic vegetable production. Cattle feces, incubated with other organic materials, are generally used as a source of nutrients for LOF production. However, other animal feces are abundantly available and might substitute cattle feces. The experiment was established to determine the effects of four animal feces on nutrient contents of tithonia-enriched LOF and its effects on the fresh weight of loose-leaf lettuce. After five weeks of incubation, the nutrient contents of LOF were analyzed. A field experiment was further established to evaluate loose-leaf lettuce responses to all LOF types. Results indicated that $\mathrm{pH}, \mathrm{N}$-total, $\mathrm{P}, \mathrm{K}, \mathrm{Mg}$, and $\mathrm{Ca}$ contents, except for C-organic, in all types of $\mathrm{LOF}$ did not significantly different. Both LOF of cattle and goat feces have similar C-organic contents $(1.02$ and $0.96 \%$, respectively) and significantly higher than of chicken and buffalo feces $(0.75$ and $0.70 \%$, respectively). All types of LOF had pH ranged from 6.66 to 6.97, N-total ranged from 1.09 to $1.26 \%$, P ranged from 1.44 to $2.78 \%$, $\mathrm{K}$ ranged from 0.57 to $0.61 \%$, $\mathrm{Mg}$-ex ranged from 0.01 to $0.02 \%$, and Ca-ex ranged from 0.03 to $0.04 \%$. This experiment suggested that the use of cattle feces for LOF production was only replaceable with goat feces. All types of LOFs produced similar lettuce fresh weight plot $^{-1}$ with the order of buffalo, chicken, goat, and cattle-based LOFs. The fresh weight of loose-leaf lettuce produced with Buffalo-based LOF was $27.5 \%$ higher than those of cattle-based LOF.
\end{abstract}

Keywords: liquid organic fertilizer; tithonia diversifolia; animal feces; nutrient content; loose-leaf lettuce.

\section{INTRODUCTION}

Production of organic vegetables is steadily increasing worldwide to meet consumer demands on healthier and safer vegetables. The use of wild Mexican sunflower, Tithonia diversifolia (Hemsl.) A. Gray, as mulching material and soil organic amendment, has been reported to increase soil productivity and crop yields [1], [2]. Green biomass of this plant has widely been applied as solid organic fertilizer in vegetable productions. The use of solid organic fertilizer was reported often takes longer time to mineralize than crop lifecycles, i.e., most composts mineralized less than $10 \%$ of initial $\mathrm{N}$ content within 4 to 6 months after application into the soil [3]. Such characteristic endorsed the use of liquid organic fertilizer (LOF) through leaves to fulfill nutrient required in organic vegetable production. Practices of using tithonia-enriched LOF to supply organic fertilizer sources in organic vegetable production have been increasingly practiced along the equatorial areas, such as in Indonesia [4].
Efforts to improve LOF effectiveness could cover the changes of green biomass used in LOF production. There are six potential sources of green masses that could be used as source of nutrients in LOF, including Tithonia diversifolia, Gliricidia sepium, Leucaena leucocephala, Ageratum conyzoides, Eichhornia crassipes, and banana corms [5]. Although green biomass is considered as one of the major sources of organic material and nutrient, animal feces, especially cattle feces, is also always included in production of LOF which serves as source of nutrients [6], [7]. It is noted that the use of local materials in organic production system is one of an important aspect to maintain land sustainability. Other types of animal feces are also abundantly available in surrounding vegetable production areas such as buffalo feces, goat feces and chicken feces. Each feces might have different nutrient contents since each animal digests different types of foods during their courses of growth and development, which eventually produce different nutrient properties in their feces. Animal manures are the potential to supply nutrients for sustainable 
production practices, especially $\mathrm{P}, \mathrm{Ca}, \mathrm{Mg}$, and $\mathrm{K}$ for plants [8]. Amending cow manure into the soil appeared to be the most viable option to improve the phosphorus and organic matter in soil because of high $\mathrm{C} / \mathrm{N}$. Both food quantity and quality consumed by animals also influence the nutrient composition in their feces.

Those above mentioned alternative animal feces have also been widely used for composting to support organic vegetable production. It was reported that the use of goatbased organic fertilizer increased the yield of sweet corn [9] and okra [10]. Besides, buffalo dung was also used as compost fertilizer [11]. The use of dairy-based vermicompost had been reported to increase the growth of greenhouse cucumber [12] and potato [13]. Chicken manure has been widely reported to increase the yield of several vegetables, such as sweet corn [14], komatsuna [15], and kale [16]. Other reports confirmed that poultry manure as an organic fertilizer had a better effect of increasing okra yield [10]. Those animal-waste fertilizers were applied as solid organic fertilizers amended into the soil for organic vegetable production. It is essential to find alternative animal feces for tithonia-enriched LOF to make use of animal wastes that available in the surrounding vegetable production areas. Recently, the use of goat feces based LOF was reported to increase the fresh weight of foliage vegetables grown in hydroponic systems [17]. Nevertheless, the use of animal feces, other than cattle, in LOF production has not been well studied. Likewise, comparison on nutrient contents of LOF produced from different animal feces has been very limitedly reported.

Loose-leaf lettuce (Lactuva sativa L.) is one of the most popular leafy organic vegetables to consumers. In addition, among different types of lettuce, loose-leaf lettuce provided the highest gross revenues. This was attributed to its higher fresh weight and higher land equivalent ratio compared to other types of lettuces [18]. By the growing interest of consumer demands to organic loose-leaf lettuce, it is important to evaluate the effectiveness of many different types of LOFs in producing this vegetable. This experiment aimed to determine the effects of four different animals (cattle, chicken, goat, and buffalo) feces on nutrient contents of tithonia-enriched LOF, as well as to compare the effects of those four types of LOFs on the yield of loose-leaf lettuce.

\section{MATERIALS AND METHODS}

This experiment was conducted from February to April 2017 in Closed Agriculture Production System (CAPS) Research Station, Faculty of Agriculture, the University of Bengkulu, located in Air Duku Village, Rejang Lebong, Bengkulu Province, Indonesia, at an elevation of approximately $1.054 \mathrm{~m}$ above sea level $\left(3^{\circ}, 27\right.$ ', 30.38" South Latitude and $102^{\circ}$. 36', 51.33' 'East Longitude).

\section{A. Determination of nutrient contents}

The production of each type of animal feces LOF was separately prepared by blending $10 \mathrm{~kg}$ animal's feces (either cattle, chicken, goat or buffalo), 201 cattle's urine, $5 \mathrm{~kg}$ of topsoil, $10 \mathrm{~kg}$ of Tithonia diversifolia (Hamsley) A. Gray), 201 solution of 24-hour incubated $20 \mathrm{ml} \mathrm{EM} 4+0.25 \mathrm{~kg}$ white sugar in a blue plastic container. These mixtures were added with water to reach a volume of 2001 , securely covered, and incubated for five weeks.

Nutrient content analysis of LOF, pH, N-total (\%), P-Bray $(\%), \mathrm{K}(\%), \mathrm{Ca}-\mathrm{ex}(\%), \mathrm{Mg}-\mathrm{ex}(\%)$, and C-organic (\%) contents was conducted using methods proposed by [28]. Each analysis of nutrient content was replicated three times, and all data were subjected to analysis of variance by using PROC GLM in Statistical Analysis System at P $<0.05$ according to the procedure for a complete randomized design. Means of nutrient contents from each animal-feces LOF were compared using Least Significantly Different test $5 \%$.

\section{B. Evaluation of LOF effects on lettuce}

Effects of four types of LOF on the yield of loose-leaf lettuce were evaluated by using a randomized completely block design with three replicates Experimental site was cleared, ploughed, harrowed, fertilized with vermicompost of 10 tons $\mathrm{ha}^{-1}$ before 12 soil-beds of $0.45 \mathrm{~m} \mathrm{x} 3 \mathrm{~m}$ were established. Each soil-bed was separated by $0.4 \mathrm{~m}$ within the block and $0.50 \mathrm{~m}$ between the blocks.

The 3-week old seedlings ( $c v$. Kriebo) were transplanted into the soil beds, arranged in single planting row with 0.30 $\mathrm{m}$ plant spacing within the rows and $0.25 \mathrm{~m}$ between the rows to make 12 plants per plot. Each LOF was sieved using a white cloth and used for application with a concentration of $100 \%$. Every plant was fertilized with a total of $630 \mathrm{ml}$ LOF during the life cycle. This volume was sprayed uniformly to plants as much as $75 \mathrm{ml}$ at 14 days after transplanting, $135 \mathrm{ml}$ at 21 days after transplanting, 180 $\mathrm{ml}$ at 28 days after transplanting, and $240 \mathrm{ml}$ at 35 days after transplanting. In the absence of precipitations, lettuce crops were manually irrigated every other two-day until the soil reached field capacity. Weeds, pests, and diseases are physically controlled.

Lettuce was harvested at 40 days after transplanting, cleaned, and its roots were removed and weighed to get its fresh weight. The effects of treatments were observed on lettuce fresh weight plot $^{-1}$. A total of 10 plants were counted since the edge plants of each soil-bed were not taken in to account. Means of treatment effects were compared using Least Significantly Different test 5\%. Data were analyzed by using PROC GLM in Statistical Analysis System at $\mathrm{P}<0.05$.

\section{RESULTS AND DISCUSSION}

\section{A. Effects on $p H$}

The $\mathrm{pH}$ of LOF is essential traits since almost all greenleaved plants survive with $\mathrm{pH}$ solution closes to neutral. Plants effectively absorb nutrient solutions that have $\mathrm{pH}$ closes to neutral range [19]. However, plant responses might vary among species and different nutrients required different $\mathrm{pH}$ level. Results indicated that $\mathrm{pH}$ of all LOFs was not significantly different from one to another $(\mathrm{Pr} .>\mathrm{F}=0.33)$, range from 6.66 to 6.97 (Figure 1). According to Indonesian National Standard (SNI 19-7030-2004), pH of organic compost should be in the range of 6.80 to 7.49 [20]. Results from this experiment indicated that all type of LOFs provide $\mathrm{pH}$ close to neutral (7.0). The magnitude of both cattle and goat based LOF was slightly lower $\mathrm{pH}$ than suggested 
standard. However, $\mathrm{pH}$ of chicken and buffalo based LOF were within the standard.

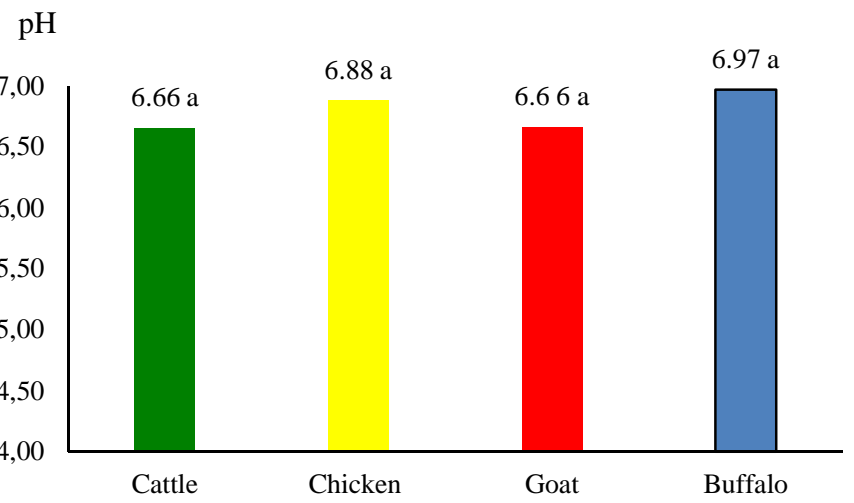

Fig. 1 Effects of animal feces sources on $\mathrm{pH}$ of LOF (Means of $\mathrm{pH}$ followed by the same letter are not significantly different according Least Significant Difference 5\%)

Results indicated that all $\mathrm{pH}$ values of studied LOFs were lower than those of solid organic fertilizer. Research conducted by [11] revealed that $\mathrm{pH}$ of solid organic fertilizer of cattle, poultry, goat and buffalo composted manures were $8.5,8.4,7.8$, and 7.7, respectively. This decreased might have attributed to microbial decomposition and the production of organic acids. From $\mathrm{pH}$ point of view, all LOFs used in this experiment had the same effectiveness to comply with standard requirement of organic fertilizer.

\section{B. Effects on N-total (\%)}

Sufficient $\mathrm{N}$ content in LOF must be available for plant to have high net photosynthesis to support its growth and development. Results from this experiment indicated that $\mathrm{N}$ content from all LOF types was not significantly different $(\mathrm{Pr} .>\mathrm{F}=0.36)$. N-total of all LOF ranged from 1.09 to $1.26 \%$ (Figure 2).

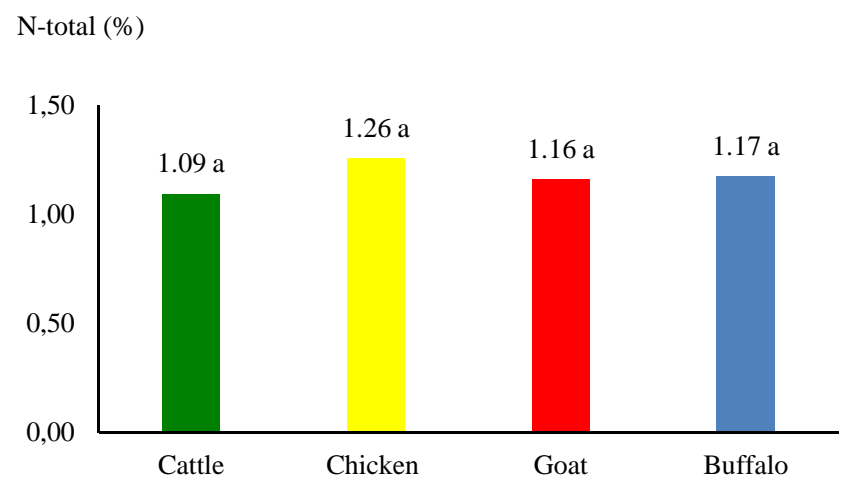

Fig. 2 Effects of animal feces sources on N-total of LOF (Means of N-total followed by the same letter are not significantly different according Least Significant Difference 5\%)

The similarity between cattle, goat and buffalo-feces based LOF might be understood since these ruminant animals consumed similar types of green biomasses. N-total of chicken-feces based LOF had similar with those of ruminant species might be related to the fact that chickens were fed with commercial poultry feeds in which its protein content was guaranteed available for chicken growth and development. Similar result was reported by [21] that N in solid organic manure was higher than those of cow dung.
Similarly, other research concluded that total $\mathrm{N}$ of poultry, goat, and dairy manures were $1.45 \%, 1.65 \%$, and $1.84 \%$, respectively [22].

The order of $\mathrm{N}$ content from this experiment, however, was different with that of reported by [15] where $\mathrm{N}$ total of solid-composted manure was in order of buffalo > poultry > cattle > goat. It is also noted that $\mathrm{N}$ contents in solid organic fertilizer was higher than those in LOF. This different between solid and liquid state of might be due $\mathrm{N}$ consumptions by bio-decomposers during the process of LOF production and also due to easily evaporation of $\mathrm{N}$.

\section{Effects on phosphorus content (\%)}

Another essential macronutrient required by plants to induce early growth and development as well as crop yields and quality is phosphorous $(\mathrm{P})$. Results indicated that $\mathrm{P}$ content from each LOF types was not significantly different $(\mathrm{Pr} .>\mathrm{F}=0.08)$ and its contents ranged from $1.84 \%$ (buffalo), $1.92 \%$ (goat), $2.16 \%$ (cattle) and $2.48 \%$ (chicken) LOF (Figure 3 ). These results were slightly different with those reported by [15] where $\mathrm{P}$ total of composted manure was in order of poultry $>$ buffalo $>$ cattle $>$ goat.

P-Bray (\%)

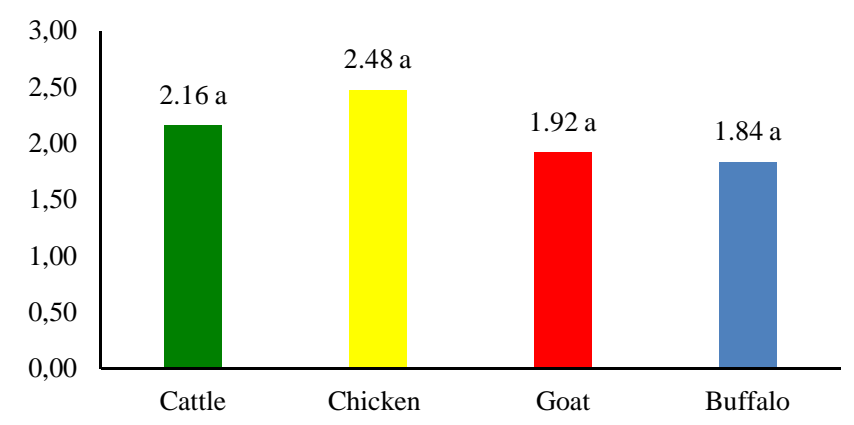

Fig. 3 Effects of animal feces sources on P-Bray of LOF (Means of P followed by the same letter are not significantly different according Least Significant Difference 5\%)

Nevertheless, $\mathrm{P}$ contents in all LOFs were higher than those in solid organic manures. Research conducted by [22] found that $\mathrm{P}$ content in poultry manure was higher than those in goat and cattle manures, accounted by $0.53 \%, 0.21 \%$, and $0.12 \%$, respectively. Another report [23] indicated that $\mathrm{P}$ content of poultry manure was higher than those of goat and cattle manures, ranged from 0.2 to $1.1 \%$. Higher $\mathrm{P}$ contents in all animal-feces LOFs compared to $\mathrm{P}$ content in solid manures might be due to addition of Tithonia diversifolia used in the production of LOF which accounted by is $0.87 \%$ [8].

\section{Effects on potassium content (\%)}

Deficiency of $\mathrm{K}$ in organic vegetable productions brings about significant problems for crops. Results from this experiment indicated that $\mathrm{K}$ content of each LOF was not significantly different $(\mathrm{Pr} .>\mathrm{F}=0.98)$ and ranged from $0.56 \%$ (buffalo), $0.57 \%$ (goat), $0.58 \%$ (cattle) and $0.61 \%$ (chicken) LOF (Figure 4). It appeared that all animal feces used in this experiment can similarly serve as $\mathrm{K}$ source in LOF production. However, the magnitude was much lower than $\mathrm{K}$ content on composted manure reported by [15], e.g., 
ranged from 6.4 to $7.86 \%$ for all types of animal-based composts (cattle, poultry, goat and buffalo). K content of solid composted manures of cattle and poultry were $2.15 \%$ and $2.05 \%$, respectively [21]. Lower of K contents of LOFs used in this experiment compared to those of solid organic fertilizer might have attributed to the formation of insoluble $\mathrm{K}$ complexes due to the presence of organic elements or changed of $\mathrm{pH}$ and eventually decreased $\mathrm{K}$ contents [15].

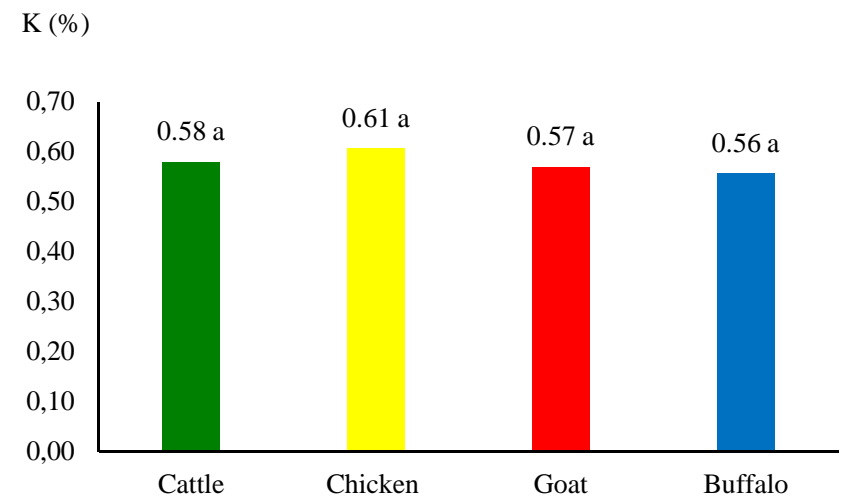

Fig. 4 Effects of animal feces sources on K of LOF (Means of K followed by the same letter are not significantly different according Least Significant Difference 5\%)

All animal feces used in this experiment can similarly serve as $\mathrm{K}$ source in LOF production. However, the magnitude was much lower than $\mathrm{K}$ content on composted manure reported by [15], e.g., ranged from 6.4 to $7.86 \%$ for all types of animal-based composts (cattle, poultry, goat and buffalo). $\mathrm{K}$ content of composted manures (solid organic fertilizer) of cattle and poultry were $2.15 \%$ and $2.05 \%$, respectively [21]. Lower of $\mathrm{K}$ contents of LOFs used in this experiment compared to those of solid organic fertilizer might have attributed to the formation of insoluble $\mathrm{K}$ complexes due to the presence of organic elements or changed of $\mathrm{pH}$ and eventually decreased $\mathrm{K}$ contents [15].

\section{E. Effects on exchangeable calcium (\%)}

Results indicated that Ca-ex of all LOF types was not significantly different from one to another $(\mathrm{Pr} .>\mathrm{F}=0.63)$ and ranged from $0.03 \%$ (cattle and buffalo based) to $0.04 \%$ (chicken and goat based) LOF (Figure 5).

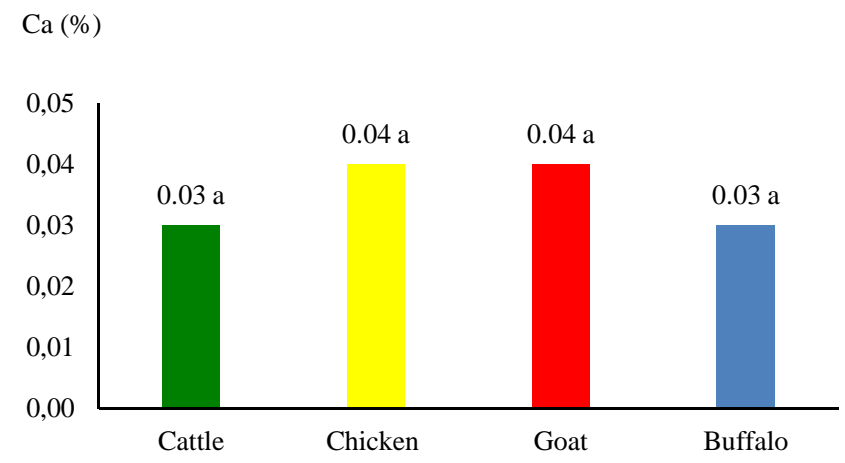

Fig. 5 Effects of animal feces sources on Ca-ex of LOF (Means of Ca-ex followed by the same letter are not significantly different according Least Significant Difference 5\%)

It appeared that $\mathrm{Ca}$ content in the sample LOFs were much lower than those of solid organic fertilizer. Ca contents in solid organic poultry and cattle manures were $3.28 \%$ and
$0.99 \%$, respectively [21]. However, this result implied the use of cattle, chicken, goat and buffalo feces had similar ability to provide $\mathrm{Ca}-\mathrm{ex}$ for LOF nutrient content.

\section{F. Effects on exchangeable magnesium (\%)}

Magnesium $(\mathrm{Mg})$ is crucially important for plant growth and development since it is responsible to maintain leaf greenness and serves as an activator for many enzyme activities. Results indicated that Mg-ex of all LOF types was not significantly different each other $(\mathrm{Pr} .>\mathrm{F}=0.81)$ and its contents ranged from $0.01 \%$ (cattle based) to $0.02 \%$ (chicken, goat and buffalo based) LOF (Figure 6).

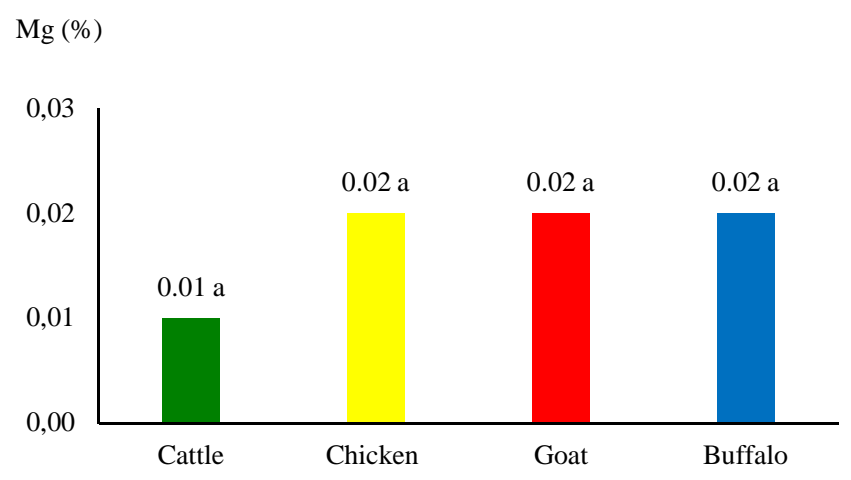

Fig. 6 Effects of animal feces sources on Mg-ex of LOF (Means of Mg-ex content followed by the same letter are not significantly different according Least Significant Difference 5\%)

The magnitudes of $\mathrm{Mg}$ in all LOF types were much lower than $\mathrm{Mg}$ of solid organic manures reported by [22] where $\mathrm{Mg}$ contents of cattle and poultry composted manures were $0.52 \%$ and $1.06 \%$, respectively.

\section{G. Effects on carbon content (\%)}

Results from this experiment indicated that type of animal feces significantly affected carbon content in LOF (Pr. $>\mathrm{F}=$ 0.01). Carbon contents of cattle and goat based LOF were significantly higher than those of in chicken and buffalo based LOF (Figure 7).

\section{C-organic (\%)}

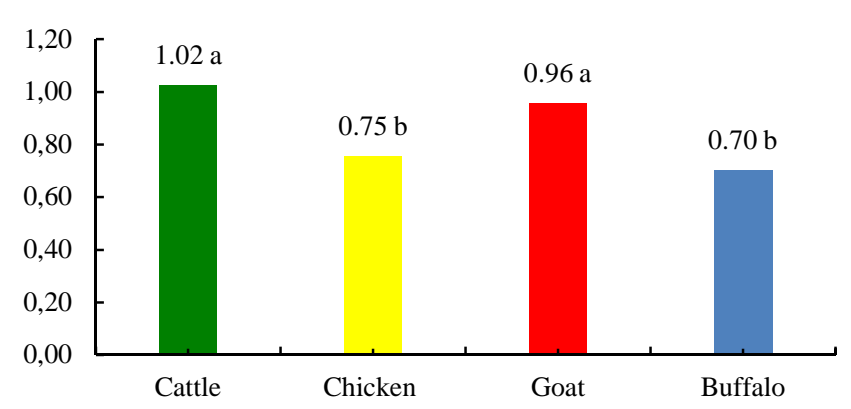

Fig. 7 Effects of animal feces sources on $\mathrm{C}$ of LOF (Means of $\mathrm{C}$ content followed by the same letter are not significantly different according Least Significant Difference 5\%)

This result was slightly different to that reported by [15] where the order of $\mathrm{C}$ in solid organic compost was cow > goat $>$ buffalo $>$ poultry. $\mathrm{C}$ of poultry manure was higher than of cow dung [21]. Although the trend of $\mathrm{C}$ is significance, it also important to note that $\mathrm{C}$ contents of 
sample LOFs were much lower than those of solid organic manures. Organic $\mathrm{C}$ of dairy cow, goat, and poultry of solid composted manures were $20.94 \%, 14.99 \%$, and $14.97 \%$, respectively [22]. Lower $\mathrm{C}$ content in liquid state than solid state might be related to biochemical processes and used of $\mathrm{C}$ by bio-decomposers.

Nevertheless, results from this experiment (Figure 2-4) indicated that nutrient contents of $\mathrm{N}, \mathrm{P}$, and $\mathrm{K}$ are higher than standard quality for organic fertilizer issued by Indonesian Standardization Board, SNI 19-7030-2004 [20]. Although this standard is addressed to solid organic compost, it could be used as basis to determine the quality for liquid organic fertilizer. According to this board, the values of total $\mathrm{N}, \mathrm{P}$ and $\mathrm{K}$ should be higher than $0.40 \%, 0.10 \%$ and $0.20 \%$, respectively. In addition, $\mathrm{Ca}-\mathrm{ex}$ and $\mathrm{Mg}$-ex of all LOF used in this experiment were very much lower than the maximum allowable values for these nutrients, i.e. $25.50 \%$ and $0.60 \%$, respectively. The magnitude of Ca-ex and $\mathrm{Mg}$ ex of studied LOF ranged from 0.03-004 \% and 0.01-0.02\%, respectively. The presence of animal feces as raw material to produce LOF is undoubtedly determined the quantity and quality of nutrients of LOFs. The variations of nutrient content of animal feces among regions might be resulted from the differences in animal feeding, farm management, and local climate conditions. Overall results of animal-based LOFs compared in this experiment suggested that goat-based LOF only substituted cattle-based LOF as source of nutrients.

It is also noted that nutrient contents of studied LOFs were much lower than those of solid organic fertilizers. Although it is considered low, the availability of LOF for plants might be more effective than solid organic fertilizer does. It was previously discussed that the availability of solid organic fertilizers was less effective compared to LOF. Superiority of LOF over solid organic fertilizers might be related to, for example, low $\mathrm{C} / \mathrm{N}$ ratio of LOFs. Results from this experiment indicated that $\mathrm{C} / \mathrm{N}$ ratios of all animal feces $\mathrm{LOF}$ are very low, i.e., $<1: 1$, indicating that $\mathrm{N}$ easily absorbed by plants. In addition, $\mathrm{pH}$ of sampled LOFs is closed to neutral which is very suitable for plants to absorb nutrients in LOF. Such characteristics enhance the effectiveness of foliar application of LOF, i.e., LOF is easily absorbed through leaf stomata, cuticula and lenticel that are located on the leaf surfaces, which eventually improve plant growth and development.

\section{H. Effects on lettuce yield}

The use of all LOF types (cattle, goat, buffalo and chicken based) have similar effects on loose-leaf lettuce fresh weight $\operatorname{plot}^{-1}(\operatorname{Pr} .>F=0.82)$. Means of treatment effects of lettuce fresh weight plot $^{-1}$ is presented in Figure 8. Similar performances of lettuce fresh weight might have related to what had previously been discussed, i.e. almost all nutrient properties of evaluated LOFs are not significantly different from one to another (Figure 1-6), except organic C (Figure $7)$. In addition, $\mathrm{C} / \mathrm{N}$ ratios of all animal feces LOF used in this experiment are very low, i.e., $<1: 1$, indicating that plants easily absorb N.

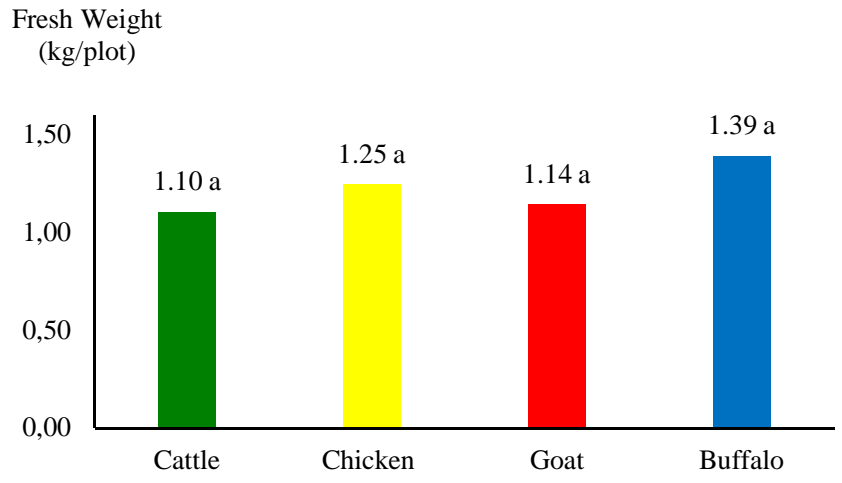

Fig. 8 Effects of animal feces sources in LOF on loose-leaf lettuce fresh weight plot-1 (Means of fresh weight content followed by the same letter are not significantly different according Least Significant Difference 5\%)

Fresh weight of loose-leaf lettuce per ha from this experiment, assuming 0.75 ha land was effectively planted, ranged from 8.28 to 10.44 tons $\mathrm{ha}^{-1}$, which are relatively closed to the description of lettuce variety used in this experiment, i.e. 10 tons $\mathrm{ha}^{-1}$. Using a plot basis fresh weight, fresh weight of loose-leaf lettuce for cattle-based, chickenbased, goat-based and buffalo-based LOFs would be as much as 8.28 tons $\mathrm{ha}^{-1}, 9.36$ tons $\mathrm{ha}^{-1}, 8.57$ tons $\mathrm{ha}^{-1}$, and 10.44 tons $\mathrm{ha}^{-1}$, respectively. These yields are comparable to those reported by Maghirang et al. [23] where organic yield of loose-leaf lettuce reached 10.96 tons ha ${ }^{-1}$ (44\% higher than non-organic lettuce). It appeared that all types of LOFs used in this experiment are suitable for production of organic loose-leaf lettuce. The superiority of the buffalo-based LOF was $26.1 \%$ higher than those of cattle-based LOF; buffalobased LOF to chicken-based and goat-based LOFs was $12.64 \%$ and $19.99 \%$, respectively. From fresh weight point of view, the use of buffalo based LOF is recommended, followed by chicken based LOF, goat-based LOF and cattlebased LOF.

This experiment employed LOF at $100 \%$ concentration. Such concentration could be decreased to have more efficient use of LOF. Crop responses to LOF were determined by concentration and volume of LOF applications [24]. Future research could be addressed to determine the effects of various LOF concentrations and volume of application on yield of loose-leaf lettuce that grown in organic production system.

\section{CONCLUSIONS}

Use of cattle feces in producing liquid organic fertilizer (LOF) was as effective as those of chicken, goat and buffalo feces in terms of $\mathrm{pH}, \mathrm{N}, \mathrm{P}, \mathrm{K}, \mathrm{Ca}-e x$ and $\mathrm{Mg}$-ex. However, C-organic contents of LOF using cattle and goat feces were significantly higher than those of chicken and buffalo feces. From the nutrient point of view, especially C-organic, the use of goat feces was effective to substitute the use of cattle feces in the production of LOF. LOFs produced by using cattle, goat, chicken and buffalo feces had similar yields (fresh weight plant ${ }^{-1}$ and fresh weight plot $^{-1}$ ). However, loose-leaf lettuce fertilized with buffalo-based LOF had higher fresh weight compared to those of other LOF sources. 


\section{ACKNOWLEDGMENT}

We are grateful for the support of the Ministry of Research, Technology and Higher Education, Indonesia for funding this project through 2016 Fundamental Research Scheme. We truly appreciate the CAPS Station of Faculty of Agriculture, University of Bengkulu for providing equipment and experimental site.

\section{REFERENCES}

[1] C.M. Aboyeji, A.O. Adekiya, O. Dunsin, G. O. Agbaje, H. O. Okoh, O. Olugbemi and T. A. J. Olofintoye. Growth, yield and vitamin C content of radish (Raphanus sativus L.) as affected by green biomass of Parkia biglobosa and Tithonia diversifolia. Agroforestry Systems, vol.93. pp. 803-812. 2019.

[2] N. Setyowati, S. Sudjatmiko, Z. Muktamar, F. Fahrurrozi, M. Chozin, and P. Simatupang. Growth and yield responses of cauliflower on tithonia (Tithonia diversifolia) compost under organic farming practices. International Journal of Agricultural Technology, vol. 14. no. 7. pp. 1905-1914. 2018.

[3] T.K. Hartz, J.P. Mitchell and C. Giannini. Nitrogen and carbon mineralization dynamics of manures and composts. HortScience. vol. 35. pp. 209-212. 2000.

[4] F. Fahrurrozi, Z. Muktamar, N. Setyowati, S. Sudjatmiko, M. Chozin. Comparative effects of soil and foliar applications of thitoniaenriched liquid organic fertilizer on yields of sweet corn in closed agriculture production system. AGRIVITA, Journal of Agricultural Science, vol. 41. no.2. pp.227-234. 2019.

[5] F. Fahrurrozi, Y. Sariasih, Z. Muktamar, N. Setyowati, M. Chozin and S. Sudjatmiko. Identification of nutrients content in six potential green biomasses for developing liquid organic fertilizer in closed agricultural production system. International Journal on Advanced Science, Engineering, Information Technology. vol. 7. pp. 559-565. 2017.

[6] Z. Muktamar, F. Fahrurrozi, P. Prawito, A.P. Sembiring, N. Setyowati, S. Sudjatmiko and M. Chozin. CO2 Emission and accumulation of soil organic matter under sweet corn stand in the long term organically managed land. International Journal of Agricultural Technology, vol.15. no.6. pp. 975-986. 2019.

[7] Z. Muktamar, S. Sudjatmiko, M. Chozin, N. Setyowati and F. Fahrurrozi. Sweet corn performance and its major nutrient uptake following application of vermicompost supplemented with liquid organic fertilizer. International Journal on Advanced Science, Engineering, Information Technology. vol. 7. pp. 602-608. 2017.

[8] R.F. Almeida, I.D.S. Queiroz, J.E.R. Mikhael, R.C. Oliveira and E.N. Borges. Enriched animal manure as a source of phosphorus in sustainable agriculture. International Journal of Recycling of Organic Waste in Agriculture, vol. 8. pp. 203-210. 2019.

[9] A.A. Alade, J. O. Azeez, G. A. Ajiboye, S. Adewuyi, T. B. Olowoboko and S. M. Hussein. Influence of Animal Manure Mixture on Soil Nitrogen Indices and Maize Growth. Russian Agricultural Science. vol. 45. pp.175-185. 2019.

[10] M.M. Khandaker, N. Jusoh, N.H. Al A. Ralmi and S.Z. Ismail. The effect of different types of organic fertilizers on growth and yield of
Abelmoschus esculentus L. Moentch (okra). Bulgarian Journal of Agricultural Science, vol. 23. no. 1. pp. 119-125. 2017.

[11] M. Irshad, A.E. Eneji, Z. Hussain and M. Ashraf. Chemical characterization of fresh and composted livestock manures. Journal of Soil Science and Plant Nutrition. vol. 13. pp. 115-121. 2013.

[12] Y. Li and N.S. Mattson. Effect of Organic Fertilizer Source and Rate on Growth and Nutrient Leachate Profile of Greenhouse-grown Cucumber. HortTechnology, vol. 29. no. 4. pp. 450-456. 2019.

[13] F. Fahrurrozi, D.N. Sari, E.R. Togatorop, U. Salamah, Z. Muktamar, N. Setyowati, M. Chozin, and S. Sudjatmiko. Yield performances of potato (Solanum tuberosum L.) as amended with liquid organic fertilizer and vermicompost. International Journal of Agricultural Technology, vol. 15. no.6. pp. 869-878. 2019.

[14] D. H. Pangaribuan, S. Sarno, Y. Liliana, S. Bahriana. Effects of Chicken Compost and $\mathrm{KCl}$ Fertilizer on Growth, Yield, Post-Harvest Quality of Sweet Corn and Soil Health. AGRIVITA Journal of Agricultural Science, vol.42. no.1. pp.131-142. 2020.

[15] L. T. Indriyati. Chicken manure composts as nitrogen sources and their effect of the growth and quality of komatsuna (Brassica rapa L.). Journal of International Society for Southeast Asian Agricultural Sciences. vol. 20. pp. 52-63. 2014.

[16] Pujiastuti, E.S., J.R. Tarigan, E. Sianturi and B.B. Ginting. The effect of chicken manure and beneficial microorganisms of EM-4 on growth and yield of kale (Brassica oleraceae acephala) grown on Andisol. IOP Conference Series Earth and Environmental Science 205(1):012020. 2018.

[17] Y. Sunaryo, D. Purnomo, M.T. Darini. V.R. Cahyani. Effects of goat manure liquid fertilizer combined with AB-MIX on foliage vegetables growth in hydroponic. IOP Conference Series Earth and Environmental Science 129(1):012003. 2018.

[18] C.S. Nascimento, C.A. Nascimento and A.B.C. Filho. Economic feasibility of lettuce intercropped with rocket in function of spacing and growing season. Rev. Caatinga, vol.31, n.1, pp.106-116. 2018.

[19] J. Ruan, J. Gerendas, R. Hardter and B. Sattelmacher. Effect of nitrogen form and root-zone $\mathrm{pH}$ on growth and nitrogen uptake of tea (Camellia sinensis) plants. Annals of Botany. vol. 99. pp. 301-310. 2007.

[20] Anonymous. Compost specification from domestic wastes. SNI 197030-2004. Indonesian Standardization Board. 2004.

[21] N.A. Tennakoon and S.D.H. Bandara. Nutrient content of some locally available organic materials and their potential as alternative Sources of nutrients for coconut. COCOS. vol. 15. pp. 23-30. 2010.

[22] M. Askegaard and J. Eriksen. Residual effect and leaching of N and $\mathrm{K}$ in cropping systems with clover and ryegrass catch crops on a coarse sand. Agriculture, Ecosystems and Environment. vol. 123. pp. 99-108. 2008.

[23] R. Maghirang, M.E. Grulla, G. Rodulfo, I.J. Madrid and M.C.P. Bartolome. Organic plant breeding: A key to improved vegetable yield and safe food. Horticulturae, vol 3. no. 1. pp. 4. 2017.

[24] D.H. Pangaribuan, Sarno, K. Hendarto, Priyanto, A.K. Darma and T. Aprillia. Liquid organic fertilizer from plant extracts improves the growth, yield and quality of sweet corn (Zea mays L. var. saccharata). Pertanika Journal of Tropical Agricultural Science, vol. 42. no. 3. pp.1157-1166. 2019. 